Portland State University

PDXScholar

World Languages and Literatures Faculty

Publications and Presentations

2005

\title{
Evolutionary Trajectories, Internet-mediated Expression, and Language Education
}

\author{
Steven L. Thorne \\ Portland State University, steven.thorne@pdx.edu \\ J. Scott Payne
}

Follow this and additional works at: https://pdxscholar.library.pdx.edu/wll_fac

Part of the Applied Linguistics Commons, and the First and Second Language Acquisition Commons Let us know how access to this document benefits you.

\section{Citation Details}

Thorne, S. L., Payne, J.S. (2005). Evolutionary Trajectories, Internet-mediated Expression, and Language Education. CALICO Journal, 22 (3), p-p 371-397.

This Article is brought to you for free and open access. It has been accepted for inclusion in World Languages and Literatures Faculty Publications and Presentations by an authorized administrator of PDXScholar. Please contact us if we can make this document more accessible: pdxscholar@pdx.edu. 


\title{
Evolutionary Trajectories, Internet- mediated Expression, and Language Education
}

\author{
Steven L. Thorne \\ J. Scott Payne \\ The Pennsylvania State University
}

\section{ABSTRACT}

This article describes the evolution of communication technologies, accompanying transformations in everyday communicative activity, and pedagogical possibilities these tools support in second and foreign language (L2) settings. We begin with an overview of synchronous computer-mediated communication (SCMC) and uses of the Internet to mediate intercultural communication for purposes of L2 learning. We then describe generational shifts in Internet technologies and their proliferation and uses, with the majority of our efforts focused on contemporary environments such as blogs, wikis, podcasting, device-agnostic forms of $\mathrm{CMC}$, and advances in intelligent computer-assisted language learning (ICALL). Throughout, we engage in a discussion of praxeological fusions of various media technologies and the implications of this nexus of practice for the transformation of what it means to teach, learn, and communicate in L2 contexts.

\section{KEYWORDS}

Synchronous Computer-mediated Communication (SCMC), Blogs, Wikis, Podcasting, Device-agnostic CMC, Intelligent Computer-assisted Language Learning (ICALL).

\section{INTRODUCTION}

This article provides a critical review of current trends in the use of technology in second and foreign language (L2) education. It also presents a preview that enumerates a number of nascent or near-future possibilities in this area. To help set the appropriate interpretive frame for readers, we wish to state at the start that this is a kinetic thought piece in which discussion ranges from demography to cognitive neuroscience, from Internet-mediated intercultural communication to podcasting, and from emerging Internet communication tools to evolving and contingent pedagogies. Our aspiration is to provide a synoptic discussion of factors relevant to L2 learning mediated by communication technologies. Our challenge is to balance significant framing questions and issues with details and con- 
crete examples and, in so doing, to provide an article that stands on its own while also acting as a broad introduction to this special issue of the CALICO Journal on computer-mediated communication in the L2 educational arena.

For applied linguists, second and foreign language (L2) researchers, language educators, program administrators, technologists, and perhaps especially for the CALICO readership that includes individuals sharing many of these interests, we have entered an historical period marked by radical transitions in how everyday communicative activity is carried out. These transitions include emerging genres of language use, an increase and diversification in patterns of information consumption, powerful possibilities for producing and disseminating information, and changes in the granularity of information sharing between spatially dispersed coworkers, friends, and family members. In educational contexts, information and communication are transmitted through an abundance of qualitatively distinctive channels to groups that often include an array of copresent as well as distributed participants, and the work students produce in these channels may vary significantly from traditional forms such as essays, paper-and-pencil tests, and term papers. And none of this is particularly noteworthy, at least not to those who directly participate in such practices on a daily basis. Within affluent regions of the world, and for affluent social classes on a global scale, this is how things are done now (for a current and sophisticated discussion of the digital divide, see van Dijk, 2005). Blended courses now include many elements that only a few years ago were only to be found in distance education contexts. Distance education may include a few weekends of face-to-face interaction over the course of a semester. Residential instruction can take the form of self-paced and solitary movement through sequenced materials with occasional interaction with an instructor. With each of these possibilities comes the question of how educational processes and outcomes relate to one another and what kind of role technology might play.

It is also clear that, unlike the CMC L2 research of the 1990s, where the use of the Internet was often treated as a proxy or heuristic to assist with the development of communicative performance within the primary foci of foreign language instruction (i.e., face-to-face communication, aural comprehension, and nondigital epistolary conventions such as letter and essay writing), Internet-mediated communication is now a high-stakes environment in its own right. Business and work activity is conducted via asynchronous and synchronous channels, interviews occur via instant messaging, educational activity is increasingly mediated by course management systems that include email, threaded discussion, and chat, while blogs and wikis, among other technologies, are increasingly incorporated into general education and L2 course activities. Furthermore, with the proliferation of digital multimedia technologies (e.g., digital video cameras and video editing software, web publishing technologies that support audio and video, and cell phones that record still images and video), computer-generated and computermediated communication now includes a multiplicity of devices and media that extend far beyond the apparatus conventionally referred to as a computer.

This article explores the evolution of new technologies and the pedagogies that they have engendered and continue to support. We begin, however, with two back- 
ground sections: the first provides an overview of synchronous computer-mediated communication (SCMC) L2 research, and the second describes increasingly prevalent uses of the Internet to mediate intercultural communication for purposes of L2 learning. We then develop a larger frame of reference for understanding technology-mediated L2 learning and use that brings together historical shifts in technology use, demographics, and what it might mean in the early $21^{\text {st }}$ century to be a highly competent communicator. Next we describe and interrogate recently evolved technologies and environments such as blogs, wikis, podcasting, deviceagnostic forms of CMC, and advances in intelligent computer-assisted language learning (ICALL). Throughout, we engage in a discussion of praxeological fusions of various media technologies, pedagogical orientations to their use, and the implications of this nexus of practice for the transformation of what it means to teach, learn, and communicate.

\section{A BRIEF HISTORY OF SCMC L2 RESEARCH}

From the early through mid 1990s, the use of SCMC, commonly referred to as chat in foreign language education, was in an exploratory phase. During this period, a flurry of studies in the SLA literature provided an amalgam of anecdotal and empirical evidence suggesting a number of pedagogical benefits for language learning (Kelm, 1992; Beauvois, 1992; Cononelos \& Oliva, 1993; Nicholas \& Toporski, 1993). The studies of Kern (1995) and Chun (1994) are widely regarded as some of the strongest of the early SCMC studies. Kern (1995) quantitatively assessed the impression that foreign language students communicate more in SCMC environments than they do in large groups in face-to-face classroom settings. Using a quasi-experimental methodology (holding constant students, time period, and topic across SCMC and face-to-face conditions), Kern compiled the following statistics from data from a second-semester French course. From a 50minute SCMC (using Daedalus InterChange) session on the topic of legalizing the French RU 486 abortion pill in the US, the total number of student messages was 172 , teacher messages were zero, and each student averaged 12.3 messages for the period. In comparison, an oral discussion by the same students on the same topic produced 95 student turns at talk and 116 instructor turns, resulting in an average student production of 5.3 turns. In sum, the SCMC treatment produced between two and three times more turns per student and a higher total number of sentences and words compared to the large-group oral discussion. Kern states that "compared to oral discussions, InterChange was found to offer more frequent opportunities for student expression and to lead to more language production" ( $p$ 470) (for current research in this area, see Abrams, 2003).

Kern also examined the linguistic quality of the SCMC discussions and concluded that "students' language output was at an overall greater level of sophistication in terms of the range of its morphosyntactic features and in terms of the variety of discourse functions expressed" (p. 470) (see also Warschauer, 1996; Böhlke, 2003, for similar results). These findings are supported by Chun's (1994) study of fourth-semester German students. Chun concluded that SCMC use promoted increased morphological complexity in non-SCMC written work over the course of 
the semester (specifically a greater ratio of complex sentences). In agreement with Kern's findings, Chun's students used a wide array of discourse features in their use of SCMC discussions. More recent research has also suggested that SCMC language use is more accurate than that of face-to-face interaction (Salaberry, 2000).

While Kern and Chun's research on L2 uses of large-group SCMC have demonstrable strengths, Ortega (1997) has noted limitations to comparing computer-mediated classroom and whole-class oral discussions. Ortega posited that the variables of group size and communicative task were not accounted for in the early SCMC research (e.g., Beauvois, 1992; Chun, 1994; Kelm, 1992; Kern, 1995). She argued that

it is justified to hypothesize that group size and equality of participation are negatively related in traditional oral interactions and positively related in computer-assisted interactions, and that the benefits of electronic over nonelectronic interactions will increase with the size of groups ... In other words, the positive equalizing effect of the electronic mode will be accentuated when comparing larger groups, as in the comparisons of teacher-fronted, wholeclass discussion with whole-class electronic discussion. (p. 86)

While this observation in no way obviates early SCMC research efforts, it calls for closer attention to key pedagogical and group size variables and also sets the stage for future work that examines the possibility of cross-modality transfer between SCMC use and oral language production.

Indeed, one of the enticing characteristics of chat for language teachers and learners has been its seeming resemblance to oral conversational exchange (e.g., Chun, 1994; for an argument against this claim, see Johanyek, 1997; see also Yates, 1996). Since a major goal of foreign language instruction is the development of oral conversational ability, the possible connection between spontaneous L2 language production via text and speech has been a long-standing focus of L2 SCMC research (Beauvois, 1997; Payne \& Whitney, 2002; Abrams, 2003; Kost, 2004; Payne \& Ross, in press). Several of these studies have employed quasi-experimental designs to compare the language produced by learners in face-to-face and online settings with respect to the volume of output, frequency of specific linguistic features, and complexity of syntax. These studies specifically asked: Can learners improve their L2 speaking ability through L2 conversation via text? Payne and Whitney (2002) investigated this question by drawing on a psycholinguistic model of language production (Levelt, 1989), together with concepts from working memory theory, to formulate principled hypotheses and predictions about the nature of cross-modality transfer. Their findings showed a significant difference in the oral proficiency gains between experimental (+SCMC) and control (-SCMC) groups. In an extension of this research, emerging CMC tools that support bimodal chat (i.e., a combination of both text and voice chat) may prove promising as an environment for future exploration of these issues (see Blake, this issue, for a report on bimodal chat). 
A substantial strand of SCMC research has examined negotiation of meaning from within the interactionist approach to second language acquisition. The interactionist hypothesis is that nonnative speakers may experience (or be given tasks that precipitate) communicative breakdowns that require negotiation to resolve. The negotiation process can include modifications on linguistic and interactional levels, and these modifications are presumed to increase the comprehensibility of the talk at hand (e.g., Long, 1985; Pica, 1987; Varonis \& Gass, 1985). This "comprehensible input" (Krashen, 1982) has been argued to promote the development of a learner's interlanguage. The notion of communicative output, first discussed by Swain (1985), offers a correction to the emphasis on communicative input by claiming that input is decipherable through largely semantic processing while output requires the communicator to syntactically parse and process the target language. These dimensions to communicative output are hypothesized to promote conscious attention to morphological and syntactic form, which, in turn, is argued to foster interlanguage development (e.g., Long, 1996; Schmidt, 1990).

A number of studies have taken the interactionist model, designed for analysis of oral interaction, and applied it to CMC learner data and task configurations. Pellettieri's (2000) research in Spanish (using Unix-based YTalk), to take one example, contrasts with the aforementioned research of Kern (1995), Chun (1994), and Beauvois (1992) in a few important respects. Whereas most research on L2 uses of SCMC had examined larger group interaction in relatively open discussions on various topics, Pellettieri focused on dyads engaged in primarily closed tasks (e.g., jigsaw tasks). Pellettieri concluded that dyadic groupings, in opposition to small and large group interaction, promoted an increase in corrective feedback and negotiation at all levels of discourse. This, in turn, prompted learners to produce form-focused modifications to their turns. Additionally, task type, specifically goal-oriented closed tasks, was positively correlated to the quantity and type of negotiations produced. In a similar study from the same period, Blake (2000) assessed the SCMC interactions of 50 intermediate learners of Spanish. Participants were arranged in dyads and asked to carry out three task types: decision making, information gap, and jigsaw. Like Pellettieri, Blake found that jigsaw tasks produced the greatest number of negotiations, but nearly all negotiations were lexical in focus, with very few negotiations addressing problems in syntax or larger units of discourse. Building on this earlier research, Smith (2003, 2004) confirmed that task type affected the extent to which learners engaged in negotiation. Significantly however, Smith also expanded the Varonis and Gass (1985) four-part model of face-to-face negotiated interaction -1) trigger $>2$ ) indicator $>3$ ) response $>4$ ) optional reaction to response-by explicitly incorporating two additional phases to represent delayed reactions to response turns that are so frequent in SCMC discourse. Smith terms these phases confirmation and reconfirmation, elements that explicitly conclude a given negotiation routine and which act as discourse markers suggesting the possibility of resuming nonnegotiation interaction (2003). Smith's careful incorporation of prior interactionist studies and development of an expanded model of computer-mediated negotiated interaction, along with other CMC specific adaptations of discourse analysis 
(Herring, 2001) and conversation analysis (Thorne, 2000), form a foundation for the continued development of analytic tools to support L2 CMC research.

We conclude this overview of CMC L2 research with a discussion of internetmediated intercultural communication for foreign language learning or "intercultural foreign language learning" (ICFLL). While such pedagogical efforts are typically and necessarily carried out using well established communication tools, and so are not particularly noteworthy in terms of pushing new technological frontiers, ICFLL presents to the foreign language learning enterprise a dynamic, if also challenging and problematic, paradigm shift.

\section{Internet-mediated Intercultural Communication in Foreign Language Education}

The conceptualization of foreign language learning and use as foremost a process of intercultural communication, in both online and offline contexts, has received significant attention in recent years (e.g., Belz, 2002, 2004; Belz \& Thorne, in press; Byram, 1997; Furstenberg, Levet, English, \& Maillet, 2001; Kinginger, 1998, 2004; Kramsch \& Thorne, 2002; Müller-Hartmann, 2000; O’Dowd, 2003; Tudini, 2003; Thorne, 2003a, in press). Whether explicitly referenced or implicitly foundational, much (though not all) of this work builds upon prior research in L2 pragmatics (Kasper \& Rose, 1999), intercultural communication theory (e.g., Scollon \& Scollon, 1995), and/or research that describes language and culture as essentially inseparable and mutually constructive phenomena (e.g., Agar, 1994; Kramsch, 1993, 1998). Internet-mediated intercultural communication used to promote L2 learning has antecedents in earlier traditions such as the educational model developed early in the $20^{\text {th }}$ century by Célestin Freinet (1994). Freinet's pedagogy included presciently modern methods such as cooperative group work, service learning, and inquiry-based learning, most of which were embedded in correspondence activities with other school children in France and around the world (for information on the still vibrant Freinet movement, see http://www. freinet.org/icem/history.htm). In its modern incarnations, the use of Internet technologies to link internationally distributed partner classes, sometimes termed telecollaboration (Warschauer, 1996; Belz, 2001, 2003; Kinginger, 2004) but which we will more descriptively refer to as intercultural communication for foreign language learning (ICFLL), proposes a compelling shift in pedagogical orientation. Rather than focusing on language per se, in relative isolation from its use in interpersonal interaction, ICFLL emphasizes the use of Internet communication tools to support dialogue, debate, collaborative research, and social interaction between internationally dispersed students. The goals are linguistic and pragmatic development and the heightening of cultural awareness of both one's home culture(s) as well as those of the interlocutors. Though ICFLL can produce tension and frustration as often as camaraderie and friendship (e.g., Belz, 2003; Kramsch \& Thorne, 2002; Thorne, 2003a), embedding the learning of a foreign language in the larger context of significant relationship development has demonstrated considerable positive effects, especially in the area of pragmatics. 
To take one example of pragmalinguistic learning outcomes in ICFLL, in a series of studies, Belz and Kinginger $(2002,2003)$ described the development of address forms used in French and German (tu/vous and $d u / S i e$, hereafter T/V). ${ }^{1}$ Current sociolinguistic research indicates that $\mathrm{T} / \mathrm{V}$ usage has become destabilized in the French and German languages (Morford, 1997; Wylie \& Brière as cited in Belz \& Kinginger, 2003). Additionally, there is sociopragmatic ambiguity around $\mathrm{T} / \mathrm{V}$ usage in textbooks and within classroom discourse. In this sense, $\mathrm{T} / \mathrm{V}$ use is not simply rule governed but is instead embedded in a system of meaning potentials that are realized in particular social interactions. Nearly all of the American participants in these interactions exhibited free variation of $\mathrm{T} / \mathrm{V}$ at the start of the intercultural communication process. Belz and Kinginger tracked usage over time in both email and SCMC sessions and found that after critical moments within exchanges with expert speaker age peers, the American participants began to systemically modify their usage. These critical moments included explicit feedback and rationales for $\mathrm{T}$ form usage from German peers. Additionally, the American students had opportunities to observe appropriate pronoun use by native speakers across synchronous and asynchronous CMC modalities. In this way, pragmatic awareness of T/V as an issue (i.e., "noticing" Schmidt, 1990, 1993) led to the approximation of expert speaker norms in most cases. Belz and Kinginger argued that the American students were motivated to maintain positive face (wanting to be liked; see Brown \& Levinson, 1987) with age peers because the relationships students were developing were significant and meaningful, and they focused students' attention on the role of linguistic form in the performance of pragmatically appropriate communication. In further research, the importance of the social relationships built in these transatlantic partnerships have been linked to positive development of other grammatical and morphological features, namely $d a$-compounds in German (Belz, 2004) and modal particles in German (Belz \& Vyatkina, 2005).

One of the more striking intercultural interventions within foreign language education is that created by Furstenberg and her colleagues (Bauer et al., in press; Furstenberg et al., 2001; Furstenberg, 2003). Developed in 1997 and continually modified and expanded since, the CULTURA project is based on the premise that L2 students can develop critical perceptions of both their own as well as another's culture through the structured juxtaposition of texts, the creation and interrogation of lexical and semantic networks, and the contestation associated with the sharing of interpretations of these data by participants in intercultural exchanges. What sets CULTURA apart from other intercultural L2 projects is its significant infrastructural development of web-based materials and activities. Students not only utilize CMC for interaction, but also engage one another through web-based questionnaires in which they make word associations (creating semantic networks), sentence completion exercises, and respond to specific situations. These responses then form the data that each partner class analyzes in an effort to notice similarities and differences and to hypothesize possible reasons for these convergences and divergences. Opinion polls are also made available so that students can discover where their analyses align within the larger context of population- 
wide national-level trends and beliefs. Increasingly over the semester, students are presented with a diverse set of parallel texts, including films (e.g., French films and their American remakes), French and American newspaper articles on the same topic but which represent divergent cultural positions, and diverse academic and literary texts. The CULTURA project's constructivist approach supports active engagement on the part of students and instructors alike. As anthropologists have noted for decades, most of what matters in culture operates at subtle levels that are difficult to capture or even to recognize. These facets of culture are "essentially elusive, abstract, and invisible. Our challenge [with CULTURA] was to make them visible, accessible, and understandable" (Furstenberg et al., 2001, p. 56). The development of multiple heuristics, material artifacts, pedagogically progressive activities, and the use of Internet information and communication technologies makes the CULTURA project particularly noteworthy as a model of institutionalized L2 learning.

\section{DEMOGRAPHICS AND STAGES OF CMC AND INTERNET ADOPTION}

In affluent regions of the world, individual and institutional uses of communication and information technologies have transformed the daily practices of work, school, and interpersonal engagement. For many, Internet mediation has become an omnipresent feature of ordinary communicative and informational activity. Indeed, when talking to high-school- and college-aged students, it is apparent that social as well as academic lives are critically mediated by participation in digital communities such as facebook (see http://www.thefacebook.com), blog networks, instant messaging, and voice and text messaging over cell phones.

In this section we turn our attention to current and near-future technologies and communicative practices. We begin by providing a demographic overview of Internet adoption and usage as a way to create a unified frame of reference for understanding the complexities of evolving Internet communication tools, changes in everyday communicative and informational activity, and how these forces are rapidly forging both a problematic gap between student populations and conventional educational practices on the one hand and are opening up possibilities for pedagogical innovation on the other. While we present a three-generation cycle representing early $\mathrm{CMC}$ use to its widespread adoption (based on data from North America), we wish to state the caveat that these overlapping phases are informed approximations. Our goal is to present a heuristic for historically contextualizing contemporary Internet use and the opportunities and challenges these demographic shifts present to education generally and L2 learning specifically.

The first broad-scale generation of Internet use spanned from the early 1980s to the early 1990s. Internet users at this time were predominantly members of scientific and computer science communities often associated with universities, government, and the defense industry. The primary communication tool was email, though the synchronous tool Unix TALK was also commonly used. Most users had a legitimate work-related reason to use the Internet, but, not surprisingly, social uses of the Internet within professional communities became commonplace (Curtis, 1998). 
The second phase began in the early 1990s and extended up through 1997-1998. University-supported accounts for faculty, staff, graduate students (and soon undergraduate students) proliferated. To accommodate growing public demand, AOL, Compuserve, and local providers such as the WELL in the San Francisco Bay Area, expanded their capacity while an increasing number of private-sector- and business-oriented Internet Service Providers sprang up to serve general population consumers. K-12 institutions were unevenly networked. Primary Internet communication tools included email and Internet Relay Chat, while primary information tools were gopher and USENET in the early 1990s, both of which became anachronistic with the development of the World Wide Web in the mid 1990s. MUDs and MOOs, ICQ, AOL Instant Messenger, as well as select other tools became popular among more sophisticated users, but email remained the preferred communication tool for everyday social, educational, and professional purposes. It was also during this phase that discussion of digital communication and information began to permeate the media; newspapers created Internet columns and digital-life weekly sections, cybercrimes were reported on television, and the public became increasingly fascinated by phenomena such as online trysts and dating services. This period was marked by generally utopian discourse positing that 'cyberspace' was a democratic, unconstrained, or less constrained, environment that instantiated many of the tenets of postmodernity (Lanham, 1993; Turkle, 1995); critical (Roszak, 1994; Stoll, 1995) and more anthropologically sophisticated perspectives also emerged (Miller \& Slater, 2000). An array of Internet related neologisms were created that proved ephemeral (e.g., Crystal, 2001; see also Thorne, 2003b for commentary), but some, such as cyberspace, virtualand e- as modifiers, proved longer lasting. People often interacted anonymously using pseudonyms, but also formed long-term relationships with others. In the case of Slashdot (http://slashdot.org) for computer geek culture and programmers, MOOs and MUDs for role playing, and USENET groups for theme- and topic-focused discussion, virtual community life was taken very seriously by participants (Dibbell, 1993; Baym, 1996).

The third generation, now upon us, includes people born during or after the mid 1980 s and who are socialized in the use of the Internet from early ages. These individuals are the first "digital natives"- - users who have literally grown up with digital literacies and communicative practices (Presky, 2001a). For the first time, email is no longer the primary conduit for everyday social, school, and work interaction. Newer tools, particularly instant messaging (Grinter \& Palen, 2002), have become dominant for social and age-peer interaction. Additionally, text messaging and voice communication over cell phones abound, as does individual and group engagement with graphically and thematically sophisticated video computer games. Equivalent in importance is the emergence of ubiquitous computing: the expectation of being able to remain in perpetual contact with peers and family members either through instant messaging or cell phones. As Presky (2001b) described it,

Our children today are being socialized in a way that is vastly different from 
their parents. The numbers are overwhelming: over 10,000 hours playing videogames, over 200,000 emails and instant messages sent and received; over 10,000 hours talking on digital cell phones; over 20,000 hours watching TV (a high percentage fast speed MTV), over 500,000 commercials seen-all before the kids leave college. And, maybe, at the very most, 5,000 hours of book reading. These are today's "Digital Native" students. (p. 1)

While Presky noted that these numbers, and we concur with his judgment, are approximations that represent relatively affluent US households and hence may vary significantly across populations and social classes, there is compelling demographic information to support these figures. Four years earlier, Tapscott (1997) proposed a similar scenario and described today's 90-million-strong school and university age population as the Net Generation (or "N-Geners"), a demographic force that thinks, performs, learns, and communicates in ways that qualitatively differ from cohorts born prior to the wide adoption of digital communication and information technologies. Through in-depth online interviews conducted with teenagers who were active participants in Freezone ${ }^{2}$ (see http://www.freezone. com), Tapscott found that N-Geners could be distinguished from previous generational cohorts in a number of ways. Most relevant for the current discussion is their demonstrated proclivity for multitasking, critical consumption of information, and the unique power position in which they find themselves as purveyors of coveted knowledge (i.e., specialized computer skills). We posit that these characteristics stand at odds with the prevailing norms of educational culture and represent a set of opportunities and challenges for language teachers (at least until digital natives occupy the role of teachers): students will process information and learn differently than their teachers, they will be less accepting of traditional definitions of "classroom" and "class participation" and the roles assigned to teachers, and they will use technology as a tool for creative expression and as a means of circumventing institutional structures.

Both Presky and Tapscott's ideas align with a materialist understanding of cognitive functioning that links ontogenetic developmental trajectories to the quality, quantity, and frequency of everyday mental activity. In other words, higher order mental functioning - what we become adept at and accustomed to-develops as a consequence of the cognitive demands of habituated activity. Neuroscience research on synaptic plasticity supports this view. Accepting that heritability also plays a role, recent neuroscience research demonstrates that phylogenetically recent cortical areas of the brain (specifically the prefrontal cortex) are hyperadaptive to use and experience. Joseph LeDoux, a leading authority in the field of cognitive neuroscience, described it this way: "People don't come preassembled, but are glued together by life" (2002, p. 3). By this, LeDoux was describing synaptogenesis, the process whereby synaptic connections form in adaptation to experiences such as physical activity, visual perception, and emotional response (see also Damasio, 2003; LeDoux, 1996) and in confrontation with cognitive tasks and problems (for a discussion of the relationship between exposure to schooling and measured gains in fluid intelligence, see Blair, Gamson, Thorne, \& Baker, 2005). 
We apply these two empirically supported arguments - that (a) cognitive engagement through everyday life experience has radically changed since the early 1990s in affluent parts of the world, and (b) everyday cognitive activity has been shown to dramatically influence synaptic development well into adulthood - to the issue of teaching and learning foreign and second languages. We propose that there now exists an amplification of the conventional "generation gap" between teachers and students, between school-delivered knowledge and performance necessary for high functioning outside of school, and, most germane to our immediate interests, between top-down processes and pedagogies that operate in formal learning environments and bottom-up life experiences of students in secondary and university environments. This gap has been confirmed by recent research by the Pew Internet and American Life Project (2002) based on focus groups (136 students in gender-balanced and racially diverse clusters) and voluntary participation data (200 students who submitted online essays describing their use of the Internet for school). The 2002 Pew report revealed that while nearly all students used the Internet as a regular part of their educational activities, little is known about how the Internet is actually used for schoolwork nor has there been adequate consideration of Internet use as it might substantively inform school policies, practices, and pedagogies.

The above discussion is meant to contextualize the following exploration of newer technologies and adaptive pedagogies that attempt to balance the resources and performance potentials of the digital-native generation with the knowledge bases, analytic traditions, and conceptual-theoretical frameworks that the institution of education can provide. To be clear, we are advocating for a critical syncretism that engenders engagement and relevance through the utilization of students' digital-literacy expertise but that also provides explicit feedback at the level of linguistic form, exposure to and movement toward mastery of a wide range of communication genres, and conscious and guided reflection on foreign language use and intercultural pragmatics (e.g., Boxer, 2002; Kasper \& Rose, 2002).

\section{RECENT AND EVOLVING TECHNOLOGIES AND THEIR USES IN L2 EDUCA- TION}

\section{Blogs and Wikis}

Blogs and wikis are considered "second generation" web applications (GodwinJones, 2003) and represent relatively modest technological advancements over their static webpage predecessor, essentially eliminating the use of HTML and FTP from the user's end. Blog and wiki technologies contribute to the argument that big innovations in use can come from relatively minor changes in code. Of the two, blogs are more commonly used by individuals, the media, and organizations and have recently come to play a significant role in public discourse, while wiki technologies create the possibility for collaboratively authored and elaborated textual production that has resulted in extraordinary resources such as wikipedia.com (described below). 


\section{Blogs}

Web logs, blogging, bloggers, the blogosphere (describing the interconnectedness of blogs with one another and other web resources, see Herring, Kouper, Paolillo, Scheidt, Tyworth, Welsch et al., 2005): contemporary nondigital media such as television and newspapers are bursting with these terms. ${ }^{3}$ Blog is a term describing a web application that displays serial entries with date and time stamps. Entries are typically presented in reverse chronological order (most recent first). Most blogs include a comments feature that allows visitors to post responses. While blogging's expressive roots tap the one-to-many dynamic of the personal web page and, by some accounts, the USENET discussion lists of the 1990s (Grohol, 2002), blogging has evolved as a set of social and informational phenomena that include mainstream media as well as grassroots and watchdog news reporting, thematic and topic-specific amateur and professional observations, business and commercial information outlets, and, of course, the 'public' journaling of one's 'private' life. ${ }^{4}$ In its short history - the first use of the term blog is variably reported to have occurred in either 1996 or 1997 and blogging as a populist movement dates only from the turn of the millennium - the rise of blogging as a form of communicative and informational expression has been mercurial. To take the example of a popular blog provider that makes public its user statistics, LiveJournal (http://livejournal.com) reports over 7 million blogs created, approximately 5 million of which have been updated at least once. Nearly 1 million of its blogs $(931,146)$ have been updated within the past 7 days, while 336,005 have been updated within the past 24 hours (posted May 25, 2005). LiveJournal reports that female-presenting bloggers outnumber users presenting as males by approximately two to one (67.3\% vs. $32.7 \%$, respectively). The ages of LiveJournal users span from 13 (35,856 blogs created by this age group) to $55(1,229)$. The $15-20$ year age group produces the majority of the blogs on this site, with a rapid taper occurring in the age range of the mid 20s. This demographic profile aligns with the "digital natives" generation discussion presented earlier, i.e., that the everyday literacy practices of current high school and college students differ significantly from that of older cohorts.

Whereas many CMC technologies are primarily interactive spaces within which certain users might dominate the flow of communication, we have come to think of blogs as "I, I, me-me-me" environments. By this characterization, we mean to emphasize the individual ownership of blog spaces. While blogs are often richly interlinked with other media, they are controlled by an individual (or a defined community in the case of a group blog) and therefore explicitly reflect an individual's (or group's) point of view. Within L2 contexts, blogging provides an alternative to writing assignments that would normally be presented only to the instructor. The chronological ordering of blog entries creates for each student an archive of their personal work that they can, and do, revisit and reflect upon. In an in-progress research project, Thorne, Weber, and Bensinger (2005a) followed high school level advanced placement Spanish foreign language students who kept weekly blog entries for a full academic year. Their preliminary analysis of 
the blog entries, survey data $(\mathrm{N}=18)$ and interview data $(\mathrm{N}=12)$ indicate that the participants had a strong preference for blogging versus traditional journals or weekly essays. All students interviewed reported that they frequently looked back over their own and others' earlier blog postings, and all but one noticed significant progress in their writing over time. Change in language production included using new phrases, improvements in spelling and the use of accent marks, and an expanded repertoire of verbal conjugations. In interviews, students reported the following: "my writing has become more fluid," "my sentences don't stand alone-I write in paragraphs now," and "I use more tenses and make an effort to incorporate whatever we're doing in class, subjunctive, conditional, whatever, into my blogs." Using activity theory (e.g., Thorne, 2003a, 2004, 2005; Thorne et al., 2005a, 2005b) to analyze interrelations between academic and social-personal CMC use, the researchers also found that blog use formed an interstice communicative space where personal expression manifested both academic and nonacademic discursive features. Students were writing both to the instructor to fulfill a class requirement while also writing to and for one another. With creative guidance from the instructor and collaboratively chosen topics and tasks, findings indicated that L2 blog use shows the potential to support the performance of multiple linguistically mediated social identities. ${ }^{5}$

In addition to its intraclass use as a journaling tool, blogging is also being used to link together study abroad students and those still at their home universities. One example, billed as a blog-based "reality show," is a partnership between Educational Directories Unlimited and the blog provider Mindsay.com that resulted in the launch of http://www.BlogAbroad.com. This service currently highlights the experiences of three study abroad students (on programs in Chile, Italy, and Senegal), each of whom keeps up a blog that is reportedly read by 500-1,000 students a week, who themselves are interested in participating in an international education program. The students abroad act as the on-site investigators, the "eyes and ears" for pre-study-abroad students. Similar projects are emerging among the Mellon cluster of 37 liberal arts colleges in the northeast of the US. While still in the exploratory phase, early reports indicate that such uses of blogs could serve a number of functions, such as providing predeparture cultural exposure for students still at their home university, helping students currently abroad to synthesize and put into narrative form their cultural and linguistic experiences, and potentially for creating predeparture orientation materials that represent specific student experiences and points of view.

\section{Wiki}

Wiki (from the Hawai'ian wiki wiki meaning 'quick') describes a web-based environment that supports collaborative writing. The "WikiWiki concept" was invented by Ward Cunningham in 1995 with a project called the Portland Pattern Repository, a computer programming site. ${ }^{6}$ While blogs are highly personal, "wikis are intensely collaborative. They feature a loosely structured set of pages, linked in multiple ways to each other and to Internet resources and an open-editing system 
in which anyone can edit any page (by clicking on the "edit this page" button)" (Godwin-Jones, 2003). The radical dimension to wiki use is its problematization of authorship. In the archetypal wiki, there is no distinction between "author" and "audience" per se since anyone who reads a wiki page can spontaneously opt to become its author. Individual wiki pages can be password limited to one or a group of users using an access control list, but wiki technology is premised on the idea of universal write/access. This freedom to create, transform, and destroy provides students with power as well as responsibility. However, many wiki engines track each addition, deletion, and modification. In the waka wiki engine, the tracking feature allows users (students) as well as instructors to precisely identify who made changes, how often, and when. Prior versions of a given page are recoverable so regression to earlier drafts is always available. Within the context of group projects, wikis enable students to adopt a "revise and roll-back" approach to the collaborative production of text and thus obviate the need to meticulously merge individual contributions in order to avoid deleting one another's work. Furthermore, determining the amount of individual participation in a group project for assessment purposes need not rely exclusively on self- and peer-assessments by group members or observational hunches by the teacher. Like an archaeological tell, a given wiki's current content is but the top layer of a temporally stratified stack of texts that precisely display the history of the writing process.

Educational projects utilizing wiki technologies are numerous. For example L*Wiki, ${ }^{7}$ supported by Penn State's national foreign language resource centerthe Center for Advanced Language Proficiency Education and Research (CALPER) - is used by a variety of groups and language courses, including Chinese, German, Russian, Spanish, English composition, and ESL. Primary uses include individual and collaborative student authoring, course project management, and multiparty running commentaries. Perhaps most dramatically, wiki technology supports a number of shared information repositories that are continually expanding, an exemplar of which is Wikipedia (see http://www.wikipedia.org), an online encyclopedia built by contributors from around the world. Currently there are entries in 199 languages. There are more than 100,000 entries each in German, French, and Japanese and more than 579,000 in English. Dutch, Polish, Spanish, and Swedish each contain more than 50,000 entries, and 14 additional languages have 10,000 or more contributions. In application to educational uses of wiki technology, recent research indicates that despite their potential to transform notions of authorship and processes of writing, wiki use does not necessarily promote the production of heterogeneous genres of text. In fact, a contrary case can be made. Based on a corpus analysis of Wikipedia and Everything2 (another wiki-based encyclopedia), Emigh and Herring (2005) found that structures of postproduction and editorial control resulted in homogeneous, formal, and standardized text types despite the expectation that multiple authors would produce a diversity of text genres. In application to wiki use in L2 contexts, Emigh and Herring's research suggests that instructors would want to clearly describe to students the purposes of the wiki-writing activity and, where appropriate, carefully structure peer- and expert-editing protocols to align with desired learning outcomes and final writing 
products. As with all technologies described in this article, task design and procedural processes are critical for fostering efficient and focused language-learning activity.

\section{iPod + Broadcasting $=$ Podcasting}

As the portmanteau suggests, podcasting is an approach for sharing and indexing mp3 audio content on the Internet to be downloaded and listened to locally on a portable mp3 player (e.g., iPod, hence the name) or computer (see also Lafford $\&$ Lafford, this issue). Podcasting can be viewed as another avenue for providing language learners with access to diverse authentic materials, building on the text and imagery available on web pages and discussion forums, as well as the audio and video streamed from Internet radio stations and television networks. Making audio available on the Internet is nothing new; however, the combination of real simple syndication (RSS) technology and applications together with portable mp3 players provides an important twist that makes podcasting a highly effective means of distributing audio (video podcasts are possible, though less frequent) and a promising tool for foreign language education. Heralded as open-source radio (Jardin, 2005a), podcasting has the capability of providing language learners with access to a discourse that diverges from the journalistic genre available through Internet radio stations. Examples include the musings of a married couple living in a farmhouse in Wisconsin to the commentary a catholic priest recorded as he was wandering through areas of the Vatican inaccessible to laypersons (Jardin, 2005b).

Submit the query podcasting + "foreign language" to Google and it becomes readily apparent that the potential benefit of podcasting to foreign language learning is on the minds of the legions of prognosticators inhabiting the blogosphere. Using "podcatching" software like iPodder, students can set a pointer to a podcasting source and configure iPodder so that it automatically checks for updates and downloads new content to an iPod and/or computer. While few examples of the integration of podcasting into foreign language instruction are currently documented, the iPod first-year experience at Duke University provides interesting case studies. Duke University students in Lisa Merschel's elementary Spanish courses, for example, have used the university's iTunes site to download listening materials and audio flash cards for improving pronunciation (e.g., a dramatic reading of Don Juan Tenorio by Duke Spanish instructors, oral comprehension exercises for use in class, and songs). These students have also created a diachronic and potentially developmental oral production portfolio by uploading weekly recordings of their own speech (see http://cit.duke.edu/ideas/newprofiles/merschel.do) In Peter McIsaac's course, "Berlin in the $20^{\text {th }}$ Century," students downloaded historical recordings of music from Berlin, famous speeches delivered in Berlin, and uploaded interviews they recorded with their iPods of Americans sharing their impressions of pivotal events in the history of Berlin (see http://cit.duke.edu/about/ipod_fac ulty_projects.do\#berlin). The Duke experiment hints at the potential for podcasting to foster a more seamless integration of in-class and out-of-class activity and 
materials, in addition to the wealth of authentic foreign language material freely available for download. In German (http://www.podcast.de), for instance, there are well over 100 podcasts currently available on a wide array of topics (e.g., news reports from Deutsche Welle read slowly, sports, science, music, and of course, op-ed pieces). When riding the bus or subway, walking across campus or through a shopping mall, students can create their own mobile immersion environments by opting to listen to foreign language content either assigned as homework or selected based on personal interest. The opportunity presented by podcasting is that it leverages habituated behavior: many students already own portable $\mathrm{mp} 3$ players and routinely download content that they listen to during downtime or transition time between activities.

The possibilities for using podcasting as a venue for students to publish original foreign language works are many. For instance, students could produce weekly or biweekly features representing their personal interests that could serve as the impetus for interclass or intercultural exchanges. Or as Ralf Borrmann at Western Reserve Academy has done with his advanced German students (Borrmann, personal communication), the radio play could be revived as a popular genre of expression that may also promote L2 development. Borrmann's students invent the characters, fashion the plot, write the script, and prepare language-learning activities for lower level students in the form of a workbook that accompanies the radio play. The appeal of radio plays in comparison to video projects is that they require less technical skill and hardware. Additionally, guides exist that describe how to compose and choreograph radio plays (See http://www.bbc.co.uk/worldservice/arts/features/howtowrite/radio.shtml).

We find podcasting an interesting addition to the text-based computer-mediated environments we have described thus far. Indeed, one of the principle critiques of textual CMC has been that oral speech and aural comprehension are not explicitly exercised. Podcasting presents a timely intersection between popular uses of iPod technologies among younger and older adults, an integration with blog cultures of one-to-many projection, and, when archived, podcasting broadcasts could be embedded as parts of larger multimodal compositions (voice, text, images, video). Like so many traditional as well as Internet-based expressive technologies, however, L2 uses of podcasting will require that instructors cultivate the delicate balance between minimally constrained creative expression and the channeling of these efforts toward concrete language use that assists students in gaining mastery of particular genres of communication (e.g., dramatic performances, readings of literature, investigative reporting, interviews, talk show formats, and monologues).

\section{MOVING TOWARD DEVICE-AGNOSTIC CMC}

It could be argued that $\mathrm{CMC}$ as a descriptive umbrella term for a genre of network-based communication tools is already anachronistic. It is increasingly the case that one does not need a "computer" (i.e., desktop or laptop device with keyboard and display) to engage in CMC. Indeed, many electronic devices have computers as an integrated component. Consider personal digital assistants (PDAs) 
and cell phones: the processing power of these devices currently exceeds the capacity of many desktop computers produced in the early to mid 1990s. This trend towards increasingly compact computing power is fueling the development of new technologies that are laying the groundwork for a new era of device-agnostic CMC. In a world of device-agnostic CMC, users can engage in synchronous communication with one another using different communicative modalities (i.e., textto-audio or audio-to-text). For instance, one interlocutor could use a cell phone with speech recognition technology, like the new Samsung p207 with VoiceMode, which automatically transcribes a caller's speech and sends the message as text to an interlocutor on another cell phone or computer. The keyboard-generated response can be either received as text or converted into speech with text-to-speech technology, a service currently offered by British Telecom to its mobile phone customers. In this example, the cell phone or computer user could either display the message via synthesized voice or as a text message. ${ }^{8}$ The crucial element to this communicative equation is choice - the ability of interlocutors to choose their preferred modality of communication.

This flexibility echoes the set of principles underlying Universal Design for Learning, a framework developed by the teachers and researchers at the Center for Applied Special Technology (http://www.cast.org) that leverages technology to support multiple means of representation, expression, and engagement. Initially conceptualized in the interest of assisting learners with disabilities, the basic tenets of this approach are supportive of providing learning environments that maximally accommodate the individual differences among all learners. Within the context of foreign language education, it is now possible to construct learning environments in which students with physical disabilities, especially visually and hearing-impaired students, can seamlessly engage in conversational exchange with peers; basic technological infrastructure will obviate the need for special accommodations. One of the most touted, if also controversial and contested (Janangelo, 1991; Spears \& Lea, 1994; Thorne, 2000, 2003a), benefits of text-based CMC is its ability to flatten hierarchy and obscure inherent personal characteristics (e.g., ethnicity, age, and gender) that may cause some people to focus on the messenger and not the message. In a CMC environment where previously incompatible communication devices and communicative modalities are supported in an integrated network, the inability to see or hear will not pose as great an impediment to communication. With appropriate technological mediation, deaf and blind individuals will be able to communicate with each other and everyone else. ${ }^{9}$

\section{FROM ICALL TO ICMC}

The inclusion of advanced computational techniques in language learning software, or intelligent computer-assisted language learning (ICALL), has been a focus of research since the early 1990s (see Holland, Kaplan, \& Sama, 1995; the special Issue of the Journal of Artificial Intelligence in Education, 1994; Gamper \& Knapp, 2002 for further discussion). Under the umbrella term of artificial intelligence, this work has focused on the application of techniques from natural language processing (e.g., parsers, taggers, etc.) and speech recognition to help 
language learners improve their pronunciation (LaRocca, Morgan, \& Bellinger, 1999; Rypa \& Price, 1999; Dalby \& Kewley-Port, 1999), assist children learning to read (Mostow \& Aist, 1999), diagnose errors and provide corrective feedback to students (see the special issue of the CALICO Journal, 2003), model and adapt to learner behavior (e.g., Bull, 1994), and support virtual dialogs or speech-interactive environments (Bernstein, Najmi, \& Ehsani, 1999; Holland, Kaplan, \& Sabol, 1999; Harless, Zier, \& Duncan, 1999).

More recently, research has begun to focus on the development of conversational agents that can interact with language learners via an instant messaging client (Zacharski, 2002; 2003). This work represents a new direction in the use of intelligent agents to support language learning by using standardized CMC tools as opposed to specialized applications to support the interaction. Zacharski has developed conversational agents that function as peers and information resources for language learners as they interact in an adventure game. The plan-based approach employed by Zacharski differs from chatterbots (e.g., Alicebot) by structuring interaction around the sort of dialogs frequently found in basal foreign language textbooks and requiring students to successfully complete a number of collaborative tasks. Learners interact with multiple conversational agents and each other via instant messaging, send and receive email messages, and view web pages in search of information to solve the required tasks (Zacharski, 2003). By customizing and integrating open-source instant messaging (e.g., Jabber), email, and web servers together into a unified framework, the system is able to keep track of what is done, when, and by whom and respond in a manner that promotes productive collaboration on the part of the human participants (Zacharski, 2003). ${ }^{10}$

\section{DISCUSSION}

This article has described long-standing CMC tools, early and more recent research on their uses in intraclass and intercultural contexts, and promising new tools and approaches to their use in L2 settings. Throughout, we have attempted to develop a number of converging lines of argumentation. The first is that CMC is evolving, increasing in ubiquity, and no longer just about text. While SCMC and asynchronous writing environments like blogs, wikis, and ICALL have continued connections to conventional computing technologies, users can interact with and through these environments from any wireless device with Internet browser capabilities. Podcasting provides expressive possibilities such as audio compositions and makes available a vast and growing number of authentic audio texts and pedagogical materials. A second issue involves changes in everyday literacies and language use. While immigrant populations to digital communication (those of us over roughly 25 years of age!) are managing quite well, many among the younger generation are growing up with communication and media experiences that differ significantly from the conventional literacies and communicative practices that had formed a relatively unbroken continuity for decades. While the precise cognitive and cultural effects of a digitally mediated life from early childhood are unclear, there is evidence to suggest an amplification of the standard generation gap that separates students from teachers and the goals of institutionalized education. 
A third point, more intimated than explicitly stated, is that the process of becoming a competent user of digital information and communication tools, largely a non-school-based process, plays a substantive role in the ways participants carry out such activity in educational settings (see Thorne, 2000, 2003a). The view that Internet communication tools are cultural artifacts is an important one; technologies are not neutral mediators of human activity but, rather, are understood by users to serve specific purposes (and not others). One of the purposes of this article has been to outline uses of emerging communication and information tools that leverage the skills and capacities that young people develop in out-of-school contexts, but also to suggest activities that value and impart the rigorous thinking, content expertise, and communicative ability (in both L1 and L2s) that instructed settings are engineered to foster.

Internet-mediated communication demonstrates an aesthetic that continues to spawn novel and widespread genres of language use. The selective and thoughtful use of SCMC, blogs, wikis, podcasting, device-agnostic CMC, and intelligent online environments holds the potential to transform L2 teaching/learning and the roles engaged in by teachers and students in the collective process of development.

\section{NOTES}

${ }^{1}$ This research was supported by a United States Department of Education International Research and Studies Program Grant (CFDA No.: 84.017A). Coprincipal investigators were J. Lantolf, C. Kinginger, and S. Thorne.

${ }^{2}$ The individuals interviewed who were part of the Freezone community cannot be characterized as typical members of their generational cohort; rather, they represent early adopters. Due to the potential sampling bias and methodologies employed in Tapscott's research, one should be cautious in making broad generalizations. Nevertheless, it is likely that the habitual behavior exhibited by the kids of Freezone will become increasingly typical of the students entering universities and colleges in North America in the years to come.

${ }^{3}$ The BBC News recently reported that the term "blog" had been the most looked-up word on the Merriam-Webster website in the year 2004 (December 1, 2004); thanks to Dorothee Schütz for alerting the authors to this information.

${ }^{4}$ According to www.blogger.com, a blog is: "A personal diary. A daily pulpit, a collaborative space. A political soapbox. A breaking-news outlet. A collection of links. Your own private thoughts. Memos to the world."

${ }^{5}$ See Gutiérrez, Rymes, \& Larson (1995) for a discussion of hybridity and its dynamic benefits within educational practice.

${ }^{6}$ Ward Cunningham describes wiki as "the simplest online database that could possibly work" (see http://wiki.org/wiki.cgi?WhatIsWiki).

7 The particular Wiki CALPER is using is a freeware Wiki called UniWakka (which is a fork of the WakkaWiki engine) that has been modified to support Unicode encoding (see http://calper.la.psu.edu/uniwiki/HomePage). 
${ }^{8}$ This capability has existed for approximately 6 months at the time this article went to press.

${ }^{9}$ The inclusiveness of device-agnostic CMC need not only apply to human beings. A further provocative wrinkle is the potential challenge to the contemporary definition of CMC: networked computers mediating communication between humans. The objectives underlying the development of the "semantic web" have already begun to open the door to the inclusion of computers as genuine conversational partners. Unlike the World Wide Web, where information is generated by humans for humans, the basic principle of the semantic web is that machines should be able to participate in the information space of the Web as "peers," with the necessary precondition being the development of languages for expressing information in a machine-processable form (Berners-Lee, 1998).

${ }^{10}$ A related and promising line of research that has not yet been harnessed for the purposes of language learning is use of stochastic techniques from information retrieval and unsupervised learning, such as latent semantic analysis (LSA) and clustering, to assist intelligent systems in formulating responses to user input. A noteworthy and extensively researched project is the Autotutor project at the University of Memphis (www.autotutor. org). Autotutor is an animated pedagogical agent that "serves as a discourse facilitator or collaborative scaffold that assists the student in actively constructing knowledge" (Person et al., 2001, p. 1) in an introductory computer literacy course.

\section{REFERENCES}

Abrams, Z. I. (2003). The effects of synchronous and asynchronous CMC on oral performance. The Modern Language Journal, 87 (2), 157-167.

Agar, M. (1994). Language shock: Understanding the culture of conversation. New York: William Morrow.

Bauer, B., de Benedette, L., Furstenberg, G., Levet, S., \& Waryn, S. (in press). Internetmediated intercultural foreign language education: The Cultura project. In J. A. Belz \& S. L. Thorne (Eds.), Internet-mediated intercultural foreign language education. Boston, MA: Heinle \& Heinle.

Baym, N. (1996). The emergence of community in computer-mediated communication. In S. Jones (Ed.), Cybersociety: Computer-mediated communication and community. Thousand Oaks, CA: Sage Publications.

Beauvois, M. H. (1992). Computer assisted classroom discussion in the classroom: Conversation in slow motion. Foreign Language Annals, 25 (5), 525-534

Beauvois, M. H. (1997). Computer-mediated communication: Technology for improving speaking and writing. In M. D. Bush \& R. M. Terry (Eds.), Technology-enhanced language learning (pp. 165-184). Lincolnwood, IL: National Textbook Company.

Belz, J. A. (2001). Institutional and individual dimensions of transatlantic group work in network-based language teaching. ReCALL, 13 (2), 129-147.

Belz, J. A. (2002). Social dimensions of telecollaborative language study. Language Learning \& Technology, 6 (1), 60-81. Retrieved June 10, 2005 from http://llt. $\mathrm{msu} / \mathrm{edu} / \mathrm{vol6num} 1 / \mathrm{belz}$ 
Belz, J. A. (2003). Linguistic perspectives on the development of intercultural competence in telecollaboration. Language Learning \& Technology, 7 (2), 68-117. Retrieved June 11, 2005, from http://lt.msu.edu/vol7num2/belz/default.html

Belz, J. A. (2004). Learner corpus analysis and the development of foreign language proficiency. System, 32 (4), 577-591.

Belz, J. A., \& Kinginger, C. (2002). The cross-linguistics development of address form use in telecollaborative language learning: Two case studies. Canadian Modern Language Review/Revue canadienne des langues vivant, 59 (2), 189-214.

Belz, J. A., \& Kinginger, C. (2003). Discourse options and the development of pragmatic competence by classroom learners of German: The case of address forms. Language Learning, 53 (4), 591-647.

Belz, J. A., \& Thorne, S. L. (Eds.). (in press). Internet-mediated intercultural foreign language education. Boston, MA: Heinle \& Heinle.

Belz, J. A., \& Vyatkina, N. (2005). Computer-mediated learner corpus research and the data-driven teaching of L2 pragmatic competence: The case of German modal particles. CALPER Working Papers, 4, 1-28. Retrieved June 10, 2005, from http: //calper.la.psu.edu/downloads/download.php?143

Berners-Lee, T. (1998). What the semantic web isn't but can represent. Retrieved June 10, 2005, from http://www.w3.org/DesignIssues/RDFnot.htm

Bernstein, J., Najmi, A., \& Ehsani, F. (1999). Subarashii: Encounters in Japanese spoken language education. CALICO Journal, 16 (3), 361-384.

Blake, R. J. (2000). Computer-mediated communication: A window on L2 Spanish interlanguage. Language Learning \& Technology, 4 (1), 120-136. Retrieved June 10, 2005, from http://lit.msu.edu/vol4num1/blake/default.html

Böhlke, O. (2003). A comparison of student participation levels by group size and language stages during chatroom and face-to-face discussions in German. CALICO Journal, 21 (1), 67-87.

Blair, C., Gamson, D., Thorne, S. L., \& Baker, D. (2005). Rising mean IQ: Cognitive demand of mathematics education, population exposure to formal schooling, and the neurobiology of the prefrontal cortex. Intelligence, 33, 93-106.

Boxer, D. (2002). Discourse issues in cross-cultural pragmatics. Annual Review of Applied Linguistics, 22, 150-167.

Brown, P., \& Levinson, S. (1987). Politeness: Some universals in language usage. New York: Cambridge University Press.

Bull, S. (1994). Student modeling for second language acquisition. Computers and Education, 23 (1-2), 13-20.

Byram, M. (1997). Teaching and assessing intercultural communicative competence. Clevedon, UK: Multilingual Matters.

Cononelos, T., \& Oliva, M. (1993). Using computer networks to enhance foreign language/ culture education. Foreign Language Annals, 26 (4), 527-534.

Chun, D. M. (1994). Using computer networking to facilitate the acquisition of interactive competence. System, 22 (1), 17-31.

Curtis, P. (1998). Not just a game: How LambdaMOO came to exist and what it did to get me back. In C. Haynes and J. R. Holmevik (Eds.), High wired: On the design, 
use, and theory of educational MOOs (pp. 25-42). Ann Arbor, MI: University of Michigan Press.

Crystal, D. (2001). Language and the Internet. Cambridge: Cambridge University Press.

Dalby, J., \& Kewley-Port, D. (1999). Explicit pronunciation training using automatic speech recognition. CALICO Journal, 16 (3), 425-446.

Damasio, A. (2003). Looking for Spinoza: Joy, sorrow, and the feeling brain. New York: Harcourt.

Dibbell, J. (1993, December 21). A rape in cyberspace. The Village Voice, pp. 36-42.

Emigh, W., \& Herring, S. (2005). Collaborative authoring on the web: A genre analysis of online encyclopedias. Proceedings of the Thirty-eighth Annual Hawaii International Conference on System Sciences (HICSS-38). Los Alamitos, IEEE Press.

Freinet, C. (1994). Oeuvres pédagogiques. Paris: Editions du Seuil.

Furstenberg, G. (2003). Reading between the cultural lines. In P. Patrikis (Ed.), Reading between the lines: Perspectives on foreign language literacy (pp. 74-98). New Haven, CT: Yale University Press.

Furstenberg, G., Levet, S., English, K., \& Maillet, K. (2001). Giving a virtual voice to the silent language of culture: The CULTURA project. Language Learning \& Technology, 5 (1), 55-102. Retrieved June 14, 2005, from http://lt.msu.edu/ vol5num $1 /$ furstenberg

Gamper, J., \& Knapp, J. (2002). A review of intelligent CALL systems. Computer Assisted Language Learning, 15 (4), 329-342.

Godwin-Jones, R. (2003). Blogs and wikis: Environments for on-line collaboration. Language Learning \& Technology, 7 (2), 12-16. Retrieved June 14, 2005, from http://lit.msu.edu/vol7num2/emerging

Grinter, R., \& Palen, L. (2002). Instant messaging in teen life. Proceedings from computer supported cooperative work 2002 (pp. 21-30). ACM.

Grohol, J. M. (2002). Psychology of weblogs: Everything old is new again. Retrieved June 1, 2005, from http://psychcentral.com/blogs/blog_new.htm

Gutiérrez, K., Rymes, B., \& Larson, J. (1995). Script, counterscript, and underlife in the classroom: James Brown versus Brown v. Board of Education. Harvard Educational Review, 65 (3), 445-471.

Harless, W., Zier, M., \& Duncan, R. (1999). Virtual dialogues with native speakers: The evaluation of an interactive multimedia method. CALICO Journal, 16 (3), 313338 .

Herring, S. (2001). Computer-mediated discourse analysis. In D. Schiffrin, D. Tannen, \& H. Hamilton (Eds.), The handbook of discourse analysis (pp. 612-634). Oxford: Blackwell Publishers.

Herring, S. C., Kouper, I., Paolillo, J. C., Scheidt, L. A., Tyworth, M., Welsch, P., Wright, E., \& Yu, N. (2005). Conversations in the blogosphere: An analysis "from the bottom up." Proceedings of the Thirty-Eighth Hawai'i International Conference on System Sciences (HICSS-38). Los Alamitos: IEEE Press.

Holland, M. V., Kaplan, J. D., \& Sama, M. R. (Eds.). (1995). Intelligent language tutors: Theory shaping technology. Mahwah, New Jersey: Lawrence Erlbaum Associates, Inc. 
Holland, M., Kaplan, J. D., \& Sabol, M. A. (1999). Preliminary tests of language learning in a speech-interactive graphics microworld. CALICO Journal, 16 (3), 339-360.

Janangelo, J. (1991). Technopower and technosuppression: Some abuses of power and control in computer-assisted writing environments. Computers \& Composition, $9(1), 47-64$.

Jardin, X. (2005a, April 27). Podcasting killed the radio star. Wired Magazine. Retrieved June 10, from http://wired-vig.wired.com/news/digiwood/0,1412,67344,00. html?tw=wn_story_top5

Jardin, X. (2005b, May 14). Audience with the podfather. Wired Magazine. Retrieved June 10, from http://www.wired.com/news/culture/0,1284,67525,00.html?tw=news letter_topstories_html

Johanyak, M. (1997). Analyzing the amalgamated electronic text: Bringing cognitive, social, and contextual factors of individual language users into CMC research. Computer and Composition, 14, 91-110.

Kasper, G., \& Rose, K. (1999). Pragmatics and SLA. Annual Review of Applied Linguistics, 19, 91-104.

Kasper, G., \& Rose, K. (2002). Pragmatic development in a second language. Oxford: Blackwell Publishers.

Kelm, O. (1992). The use of synchronous computer networks in second language instruction: A preliminary report. Foreign Language Annals, 25 (5), 441-454.

Kern, R. G. (1995). Restructuring classroom interaction with networked computers: Effects on quantity and characteristics of language production. The Modern Language Journal, 79 (4), 457-476.

Kinginger, C. (1998). Videoconferencing as access to spoken French. The Modern Language Journal, 82 (4), 502-513.

Kinginger, C. (2004).Communicative foreign language teaching through telecollaboration. In K. van Esch \& O. St. John (Eds.), New insights into foreign language learning and teaching (pp. 101-113). Frankfurt am Main: Peter Lang.

Kost, C. R. (2004). An investigation of the effects of synchronous computer-mediated communication (CMC) on interlanguage development in beginning learners of German: Accuracy, proficiency, and communication strategies. Unpublished doctoral dissertation, University of Arizona, Tucson.

Kramsch, C. (1993). Context and culture in language teaching. Oxford: Oxford University Press.

Kramsch, C. (1998). Language and culture. Oxford: Oxford University Press.

Kramsch, C., \& Thorne, S. L. (2002). Foreign language learning as global communicative practice. In D. Block and D. Cameron (Eds.), Globalization and language teaching (pp. 83-100). London: Routledge.

Krashen, S. (1982). Principles and practices in second language acquisition. New York: Pergamon Press.

Lanham, R. (1993). The electronic word: Democracy, technology, and the arts. Chicago: University of Chicago Press.

LaRocca, S., Morgan, J., \& Bellinger, S. (1999). On the path to 2X learning: Exploring 
the possibilities of advanced speech recognition. CALICO Journal, 16 (3), 295 310 .

LeDoux, J. (1996). The emotional brain. New York: Touchstone.

LeDoux, J. (2002). Synaptic self: How our brains become who we are. New York: Penguin.

Levelt, W. J. M. (1989). Speaking: From intention to articulation. Cambridge: The MIT Press.

Long, M. (1985). Input and second language acquisition theory. In S. M. Gass \& C. G. Madden (Eds.), Input in second language acquisition (pp. 377-393). Rowley, MA: Newbury House.

Long, M. (1996). The role of the linguistic environment in second language acquisition. In W. Ritchie \& T. Bhatia (Eds.), Handbook of second language acquisition (pp. 413-468). New York: Academic Press.

Miller, D., \& Slater, D. (2000). The Internet: An ethnographic approach. Oxford: Berg.

Morford, J. (1997). Social indexicality in French pronominal address. Journal of Linguistic Anthropology, 7 (1), 3-37.

Mostow, J., \& Aist, G. (1999). Giving help and praise in a reading tutor with imperfect listening - because automated speech recognition means never being able to say you're certain. CALICO Journal, 16 (3), 407-424.

Müller-Hartmann, A. (2000). The role of tasks in promoting intercultural learning in electronic learning networks. Language Learning \& Technology, 4 (2), 129-147. Retrieved June 10, 2005, from: http://lit.msu.edu/vol4num2/muller

Nicholas, M. A., \& Toporski, N. (1993). Developing “The Critic's Corner:” Computer assisted language learning for upper-level Russian students. Foreign Language Annals, 26 (4), 469-478.

O'Dowd, R. (2003). Understanding the "other side:” Intercultural learning in a SpanishEnglish e-mail exchange. Language Learning \& Technology, 7 (2), 118-144. Retrieved June 10, 2005, from: http://1lt.msu.edu/vol7num2/odowd

Ortega, L. (1997). Processes and outcomes in networked classroom interaction: Defining the research agenda for L2 computer-assisted classroom discussion. Journal of Language Learning \& Technology, 1 (1), 82-93. Retrieved June 10, 2005, from http://llt.msu.edu/vol1num1/ortega/default.html

Payne, J. S., \& Ross, B. (in press). Working memory, synchronous CMC, and L2 oral proficiency development. Language Learning \& Technology.

Payne, J. S., \& Whitney, P. J. (2002). Developing L2 oral proficiency through synchronous CMC: Output, working memory, and interlanguage development. CALICO Journal, 20 (1), 7-32.

Pellettieri, J. (2000). Negotiation in cyberspace: The role of chatting in the development of grammatical competence. In M. Warschauer \& R. Kern (Eds.), Network-based language teaching: Concepts and practice (pp. 59-86). New York: Cambridge University Press.

Person, N. K., Graesser, A. C., Bautista, L., Mathews, E. C., \& the Tutoring Research Group (2001). Evaluating student learning gains in two versions of AutoTutor. In J. D. Moore, C. L. Redfield, \& W. L. Johnson (Eds.), Artificial intelligence in 
Education: AI-ED in the wired and wireless future (pp. 286-293). Amsterdam, IOS Press.

Pew Internet and American Life Project. (2002). The digital disconnect: The widening gap between Internet-savvy students and their schools. Retrieved June 10, 2005 from http://www.pewinternet.org/pdfs/PIP_Schools_Internet_Report.pdf

Pica, T. (1987). Interlanguage adjustments as an outcome of NS-NNS negotiation interaction. Language Learning, 38 (1), 45-73.

Presky, M. (2001a, October). Digital natives, digital immigrants. On the Horizon. NCB University Press, 9 (5).

Presky, M. (2001b, December). Digital natives, digital immigrants, Part II: Do they really think differently? On the Horizon. NCB University Press, 9 (6).

Roszak, T. (1994). The cult of information (2nd ed.). Berkeley: University of California Press.

Rypa, M., \& Price, P. (1999). VILTS: A tale of two technologies. CALICO Journal, 16 (3), 385-404.

Salaberry, R. (2000). L2 morphosyntactic development in text-based computer communication. Computer Assisted Language Learning, 13 (1), 5-27.

Schmidt, R. (1990). The role of consciousness in second language acquisition. Applied Linguistics, 11 (2), 219-258.

Schmidt, R. (1993). Awareness and second language acquisition. Annual Review of Applied Linguistics 13, 206-226.

Scollon, R., \& Scollon, S. (1995). Intercultural communication. Cambridge: Blackwell Publishers.

Smith, B. (2003). Computer-mediated negotiated interaction: An expanded model. The Modern Language Journal, 87 (1), 38-57.

Smith, B. (2004). Computer-mediated negotiated interaction and lexical acquisition. Studies in Second Language Acquisition, 26 (3), 365-398.

Spears, R., \& Lea, M. (1994). Panacea or panopticon? The hidden power in computer-mediated communication. Communication Research, 21 (4), 427-459.

Sprague, D., \& Dede, C. (1999). Constructivism in the classroom: If I teach this way, am I doing my job? Learning and Leading with Technology, 27 (1), 6-9, 16-17.

Stoll, C. (1995). Silicon snake oil: Second thoughts on the information highway. New York: Doubleday.

Swain, M. (1985). Communicative competence: Some roles of comprehensible input and comprehensible output in its development. In S. M. Gass \& C. G. Madden (Eds.), Input in second language acquisition (pp. 235-253). Rowley, MA: Newbury House.

Tapscott, D. (1997). Growing up digital: The rise of the net generation. New York: McGraw-Hill.

Thorne, S. L. (2000). Beyond bounded activity systems: Heterogeneous cultures in instructional uses of persistent conversation. Proceedings of the Thirty-Third Annual Hawaii International Conference on System Sciences (HICSS-33). Los Alamitos, IEEE Press. 
Thorne, S. L. (2003a). Artifacts and cultures-of-use in intercultural communication. Language Learning \& Technology, 7 (2), 38-67. Retrieved June 10, 2005, from: http://lit.msu.edu/vol7num2/thorne

Thorne, S. L. (2003b). [Review of Language and the Internet] The biggest language revolution ever meets applied linguistics in the 21st century. Language Learning \& Technology, 7 (2), 24-27. Retrieved June 10, 2005, from http://lit.msu.edu/ vol7num $2 /$ review $1 /$ default.html

Thorne, S. L. (2004). Cultural historical activity theory and the object of innovation. In O. St. John, K. van Esch, \& E. Schalkwijk (Eds.), New insights into foreign language learning and teaching (pp. 51-70). Frankfurt: Peter Lang Verlag.

Thorne, S. L. (2005). Epistemology, politics, and ethics in sociocultural theory. The Modern Language Journal, 89, 393-409.

Thorne, S. L. (in press). Pedagogical and praxiological lessons from Internet-mediated intercultural foreign language learning research. In J. Belz \& S. L. Thorne (Eds.), Internet-mediated intercultural foreign language education. Boston: Heinle \& Heinle Publishers.

Thorne, S. L., Webber, D., \& Bensinger, A. (2005a, May). Interactivity system analysis, AIM, and pedagogical innovation. Paper presented at the 2005 CALICO conference, East Lansing, MI.

Thorne, S. L., Webber, D., \& Bensinger, A. (2005b). Mediation and interactivity system analysis in and out of school: Instant messaging and blogging in L2 education. Manuscript in preparation.

Turkle, S. (1995). Life on the screen: Identity in the age of the Internet. New York: Simon \& Schuster.

Tudini, V. (2003). Using native speakers in chat. Language Learning \& Technology, 7 (3), 141-159. Retrieved June 10, 2005, from: http://lt.msu.edu/vol7num3/tudini/de fault.html

Van Dijk, J. (2005). The deepening divide: Inequality in the information society. London: Sage.

Varonis, E., \& Gass, S. (1985). Non-native/non-native conversations: A model for negotiating meaning. Applied Linguistics, 6 (1), 71-90.

Warschauer, M. (1996). Computer-mediated collaborative learning: Theory and practice. The Modern Language Journal, 81 (4), 470-481.

Yates, S. (1996). Oral and written aspects of computer conferencing. In Susan Herring (Ed.), Computer-mediated communication: Linguistic, social and cross-cultural perspectives (pp. 9-46). Philadelphia: John Benjamins Publishing Company.

Zacharski, (2002). Conversational agents for language learning. Unpublished manuscript.

Zacharski, (2003). A discourse system for conversational characters. In A. Gelbukh (Ed.), Proceedings of the fourth international conference on intelligent text processing and computational linguistics (pp. 492-495). Heidelberg: Spring Verlag. 


\section{ACKNOWLEDGEMENT}

We are indebted to Julie Belz for her comments on an earlier draft of this article.

\section{AUTHORS' BIODATA}

Steve Thorne is the Associate Director of the Center for Language Acquisition, Associate Director of the Center for Advanced Language Proficiency Education and Research (a National Foreign Language Resource Center), and Assistant Professor in Linguistics and Applied Language Studies at The Pennsylvania State University. His research addresses activity theory, additional language learning, and computer-mediated communication.

J. Scott Payne (Ph.D. Washington State University) is Senior Lecturer in the Department of Linguistics and Applied Language Studies, Assistant Director for Technology and Research at the Center for Language Acquisition, and Co-Director of the Technology Project under the Center for Advanced Language Proficiency Education and Research (CALPER) at The Pennsylvania State University. His research and publications have focused on the intersection between technology and SLA theory and practice with particular attention to the role that individual differences in working memory capacity play in computer-mediated language learning. He is also actively engaged in the development of web applications to support psycholinguistic and corpus-based SLA research and CALL.

\section{AUTHORS' ADDRESSES}

Steven L. Thorne

Department of Linguistics and Applied Language Studies

The Pennsylvania State University

304a Sparks

University Park, PA 16802

Phone: 814/863-7036

Fax: 814/865-7944

Email: sthorne@psu.edu

J. Scott Payne

Department of Linguistics and Applied Language Studies

The Pennsylvania State University

5c Sparks

University Park, PA 16802

Phone: 814/865-1323

Fax: 814/865-7944

Email: jspayne@psu.edu 